\title{
IDENTIDAD Y FUGA. CLAVES AMERICANAS EN EL TURBIÓN DE JOSÉ LUIS ACQUARONI
}

\author{
José Manuel Camacho Delgado \\ (Universidad de Sevilla) \\ jcamacho@us.es
}

\begin{abstract}
Para Cristina Mercedes, un turbión azul y lleno de risas, entre Sevilla y Sanlúcar.

Para las gemelas Mercedes Oliver e Isabel Peña, Maestrísimas de altos vuelos, universalizando mi patria sanluqueña.
\end{abstract}

RESUMEN: En 1967, el escritor José Luis Acquaroni publicaba su novela $E l$ turbión en la que daba buena cuenta de los disturbios sociales originados tras la caída del dictador venezolano Marcos Pérez Jiménez. A partir del error cometido con la identidad de un inmigrante andaluz, llamado Efrén, quien es confundido con uno de los torturadores del régimen, este se ve obligado a huir durante veinticuatro horas para poner a salvo su vida. En su desplazamiento por la ciudad (trasunto de Caracas) el lector asiste a una ola incontrolada de violencia, con todo tipo de linchamientos, y al saqueo indiscriminado de multitud de negocios y establecimientos comerciales, poniendo al descubierto el lado más sórdido de la sociedad.

Palabras Clave: José Luis Acquaroni, El turbión, Marcos Pérez Jiménez, dictadura, saqueo, violencia.

\section{IDENTITY AND ESCAPE. AMERICAN KEYS IN EL TURBIÓN BY JOSÉ LUIS ACQUARONI}

ABSTRACT: In 1967, the writer José Luis Acquaroni published his novel El turbión, where he took into consideration the social disturbs caused by the overthrow of the Venezolan dictator Marcos Pérez Jiménez. From the mistake made with the identity of an Andalusian immigrant called Efrén, who is confused with one of the regime's torturer, he is forced to run away during twenty four hours in order to safe his own life. During his travel around the city (transcript Caracas) the reader witness an outbreak of uncontrolled violence with all types of lynching, and the indiscriminate looting of several business and commercial outlets, uncovering the most sordid side of the society.

KEYwords: José Luis Acquaroni, El turbión, Marcos Pérez Jiménez, dictatorship, looting, violence.

\section{LA POSTDICTADURA Y EL SAQUEO}

En 1971, el periodista Ernesto González Bermejo le hacía una entrevista a García Márquez para la extinta revista Triunfo, en donde le preguntaba por la imagen fundacional que había originado El otoño del patriarca (1975). García Márquez respondía lo siguiente: 
Sé de dónde me vino la idea de escribir el libro sobre el dictador. En Caracas, a principios de mil novecientos cincuenta y ocho, cuando cayó Pérez Jiménez.

Pérez Jiménez ya se había ido. La Junta del Gobierno estaba reunida en un salón de Miraflores, y en la antesala estábamos todos los periodistas de Caracas, a las cuatro de la mañana, esperando desde toda la noche el anuncio del destino de este país que se estaba jugando en ese cuarto.

En un cierto momento, por primera vez, se abrió la puerta y me salió un oficial en uniforme de campaña, con las botas embarradas, caminando de espaldas, apuntando hacia dentro con una metralleta [...]. No sé quién era ese militar, sé que se asiló en Santo Domingo. Pero en ese instante, y no sé cómo, tuve la intuición de lo que es el poder (en Rentería Mantilla, 1979: 57).

Unos años más tarde, en sus conversaciones con Plinio Apuleyo Mendoza, recogidas en El olor de la guayaba, un García Márquez pletórico, que sabe que va a ganar el Premio Nobel de literatura, volvía a recrear este episodio clave en su mirada narrativa:

A bordo del avión iba el dictador con su mujer y sus hijas, sus ministros y sus amigos más cercanos. Tenía la cara inflamada por una neuralgia, y estaba enfurecido con su edecán porque en la precipitación de la fuga, al pie del avión, al que subieron por una escala de cuerda, había olvidado un maletín con once millones de dólares.

Ganando altura, el aparato se alejaba ya hacia el mar, hacia el Caribe, cuando el locutor de la radio, interrumpiendo programas de música clásica que habíamos oído durante tres días, anunció la caída de la dictadura. Una tras otra, como bujías de un árbol de Navidad, fueron encendiéndose luces en las ventanas de Caracas. El delirio empezaría después, en la neblina y el aire fresco de la madrugada. Bocinas, gritos, sirenas de fábricas, gentes agitando banderas en autos y camiones. Poco antes de que ardiera el edificio de la Seguridad Nacional, la multitud había sacado en hombros a los presos políticos que allí se encontraban.

Era la primera vez que veíamos la caída de un dictador en América Latina (en Mendoza, 1982: 116).

El Nobel colombiano recreó muchas veces la imagen de un militar que irrumpía en la sala en la que estaban reunidos los periodistas, metralleta en mano, caminando de espaldas, «manchando la alfombra con el barro de sus botas» (Mendoza, 1982: 117) como una imagen fundacional de la narrativa del poder, seguida de esa celebración contagiosa que se desparrama por la ciudad como un calambre para celebrar a golpe de claxon la caída del régimen y el triunfo de la libertad. Esa imagen, ampliamente difundida y comentada en la crítica garcimarquiana, contrasta con las tesis narrativas e ideológicas de El turbión ${ }^{1}$ de José Luis Acquaroni en donde se plantea, de alguna forma, el reverso de la historia, las costuras de un tapiz ambiguo y complejo, los repliegues y puntadas de una realidad que convierte un mismo episodio en fuente de interpretaciones tan dispares como inagotables, porque frente a la euforia descrita por el autor de Cien años de soledad, la novela de Acquaroni es una suerte de ajuste de cuentas con la violencia desmedida que asoló a la capital venezolana en los días posteriores a la caída del dictador Marcos Pérez Jiménez, lo que lleva a uno de los personajes a decir que este país «había hecho de las guerras civiles su primera industria

${ }^{1}$ Barcelona, Biblioteca AlSur de $A B C$, 2002. Prólogo de José Jurado Morales. Cito siempre por esta edición en el propio texto. 
nacional» (p. 34). En un panorama cultural atrofiado, como fue el de la posguerra y el tardofranquismo, el escritor sanluqueño tuvo que defenderse en más de una ocasión de las críticas ideológicas que se vertieron sobre su obra, considerándola complaciente con los postulados políticos de la dictadura depuesta, como se desprende de estas declaraciones:

Parece que existe como el temor de comprometerse políticamente si se habla de $E l$ Turbión. Una abierta condenación de la violencia como instrumento de elección para hacerse con el poder político — que ésa es la tesis de mi libro- parece que ha querido identificarse con una defensa del «perejimenismo», cuando mis noticias son que el general se hizo también con el poder tras un golpe de fuerza. En fin: que en cuanto se roza ligeramente el tema político, uno tiene necesariamente que despeñarse por una $\mathrm{u}$ otra ladera. No se acepta que uno pueda mantenerse en el centro, en una posición de verdadera objetividad, ¡qué triste es esto! (en Arroyo García, 2000: 126).

El trasfondo de la novela es, sin duda alguna, la caída del dictador Marcos Pérez Jiménez, cuyo desenlace está repleto de elementos con un considerable potencial literario y cinematográfico. De hecho, en la novela se habla de la huida de un «dictador, que escapó en avión de madrugada»(p. 22), y son muchos los personajes que son conscientes de este episodio por el ruido ensordecedor de los motores del avión presidencial (p. 33), aunque nunca se nombra al sátrapa caído en desgracia, ni tampoco se dan mayores datos sobre la localización geográfica de la novela, más allá de que se trata de una república latinoamericana, con visos de formar parte de la sórdida galería de las repúblicas bananeras, siguiendo el paradigma del Nostromo (1904) del escritor polaco-británico Joseph Conrad. De manera deliberada, Acquaroni ha concebido una ficción sobre un espacio innominado, ajeno a la tiranía del dato empírico, un espacio que puede tener todos los anclajes en la realidad, pero que también puede ser leído como una metáfora de la constante inestabilidad política heredada tras los procesos de independencia de los territorios españoles de ultramar.

Sabemos que se trata de la Venezuela que conoció la caída del dictador Pérez Jiménez, tal y como ha señalado José Jurado en su prólogo a El turbión, momento que vivió en sus carnes el escritor sanluqueño, después de una estancia larga en el país caribe:

Poco después de publicar la novela corta El cuclillo de la madrugada [...], en el verano de 1956, el Instituto de Cultura Hispánica de Madrid le encarga a Acquaroni que diserte sobre aspectos de la literatura española, en especial sobre la última poesía y sobre el Quijote, en países como Puerto Rico, Venezuela, Colombia y Santo Domingo. Durante esa estancia colabora en la organización del I Festival del Libro de América celebrado en Venezuela en 1956. Terminado el festival, comienza a dirigir la Imprenta Universitaria, adscrita a la Escuela de Periodismo de la Universidad Central de Venezuela, y el Departamento de Adquisiciones de la Biblioteca de esta Universidad. De modo que la primitiva estancia transitoria se convierte en un periodo de cuatro años, de 1956 a 1960 (Jurado, 2020: 416). ${ }^{2}$

2 José Jurado apunta, incluso, al posible origen intertextual de la novela a partir de dos obras previas que corrieron una suerte desigual: «En 1966 se le otorga el tercer puesto en el certamen "Alfaguara" de novela por Zarabunda para Efrén. A finales de este año, el 29 de diciembre, consigue el segundo puesto en el "Ateneo de Valladolid" de novela corta por El mal naipe, tras Leopoldo Cortejoso por Siete caras en un espejo. Casi con toda seguridad Zarabunda para Efrén y El mal naipe son los textos originarios, aunque quizá incompletos o con modificaciones, de El turbión, la obra que consigue el 9 de 
Sin embargo, más allá de este dato verificable, reivindicado por el propio José Luis Acquaroni en las palabras iniciales de su novela, lo cierto es que el territorio en el que se desarrolla la acción está lleno de contornos imprecisos, con una cartografía inaprensible, que permite activar de manera eficaz la necesaria estrategia de deslocalización narrativa y de universalización del drama humano que pretende contar. ${ }^{3}$ Algunos nombres de calles, de edificios y de plazas dan cierta sensación de veracidad y verosimilitud al relato - la Plaza Bolívar, la calle Real, el palacio de la Gobernación, la Universidad Central-, pero lo importante es que la acción de la novela no transcurre propiamente en un espacio físico, sino mental y psicológico, el del fracaso de las utopías sociales y el triunfo de la tiranía, que convierte a numerosos países en auténticos esperpentos de la civilización, en la línea de obras clásicas como el Tirano Banderas de Valle-Inclán (1926) o El Señor Presidente (1946) de Miguel Ángel Asturias. ${ }^{4}$

Lo verdaderamente original de la novela ha consistido en desplazar su punto de vista desde un metagénero que está dando sus primeros pasos, como es el de la novela de la dictadura, ${ }^{5}$ que triunfará en la década de los años setenta, para centrarse en otra forma de narración que podríamos llamar psicológica, donde se recrean los complejos mecanismos del miedo que actúan sobre el individuo a partir de los comportamientos violentos e irracionales de colectivos que pierden su singularidad para convertirse en una masa uniforme que solo busca la venganza y el saqueo como formas de redención social, tal y como estudiara a finales del siglo XIX el psicólogo y sociólogo francés Gustave Le Bon en La psicología de las masas (1895).

El turbión narra una huida, la del emigrante (posiblemente sanluqueño) Efrén, un albañil que lleva siete años trabajando en el país caribe, quien va a ser confundido con un espía o con alguno de los esbirros y torturadores del régimen dictatorial depuesto, lo que provocará su fuga, y es en este movimiento centrífugo en busca de algún lugar seguro lo que permite a José Luis Acquaroni ensartar de manera episódica las situaciones más extrañas e insólitas que el protagonista va a vivir a lo largo de

marzo el "II Premio Blasco Ibáñez" 1967 de novela, y que en algún momento el autor quiso titular la Caribera. Con el seudónimo de Alvar Fáñez Minaya, Acquaroni consigue las 100.000 ptas. de un certamen al que concurren 118 novelas y en el que queda finalista Juan Pla con Mientras crece el día» (Jurado, 2000: 32).

${ }^{3}$ El propio José Luis Acquaroni se quejaba de la incomprensión recibida tras la publicación de la novela: «Algunos venezolanos parece que se han molestado porque no sitúo explícitamente El turbión en Caracas. La identificación es total. Ellos se sienten aludidos, pero no nombrados [...]. Mis propósitos eran que El turbión, más que una crónica histórica, fuera un testimonio social, una diatriba contra la violencia [...], como medio de escalar el poder político» (en Arroyo García, 2000: 120).

${ }^{4}$ Según declaraciones del propio José Luis Acquaroni, recogidas por Alejandra Arroyo entre los papeles personales del escritor, este reconoce la necesidad de acercarse al metagénero narrativo de la dictadura. Sin embargo, el comentario que reproduzco a continuación, no fechado en esta cita, puede estar un tanto deslocalizado temporalmente, ya que todavía son muy escasas las muestras de novelas del dictador (o de la dictadura) en los años sesenta, y hay que esperar a la década siguiente, a partir de los continuos golpes de estado perpetrados por las fuerzas militares en el cono sur americano, para que surja con inusitada fuerza esta particular modalidad narrativa: «En el Centro de Cultura Hispánica conseguí una beca para dar conferencias en Hispanoamérica [...]. Cuando terminaron mis conferencias en Puerto Rico, Venezuela, Colombia y Santo Domingo, coincide con la inauguración del primer festival del libro y Pedro Grases me reincorpora a su equipo. Me quedo a trabajar con él en la biblioteca de la Universidad Central de Caracas hasta el derrocamiento de Pérez Jiménez. Cuando vuelvo a España por 1960, me encuentro con la necesidad de abordar la novela, ahora yo traía un tema que necesitaba un desarrollo amplio, era el tema del dictador tan tocado en la novela hispanoamericana. Así nació El Turbión» (en Arroyo García, 2000: 120-121).

5 Véanse los trabajos de Zuluaga (1977), Calviño (1985), Sandoval (1989), Noguerol Jiménez (1992) y Camacho Delgado (2016). 
veinticuatro interminables horas, dejando para el lector una radiografía descarnada de la sociedad capitalina. Como han estudiado entre otros filósofos de la historia, Jean Delumeau en su clásico El miedo en Occidente (1978), el miedo es un resorte necesario para romper una situación de equilibrio inicial. El miedo activa la necesidad de fuga, pone en alerta a las posibles víctimas, afila la intuición y los mecanismos de supervivencia, ayuda a vivir y a sobrevivir. Por ello, mientras que Efrén y sus compañeros están en la Pensión Orense, aparentemente ajenos a la barbarie que está ocurriendo a escasos metros, el narrador se encarga de trazar con mano certera algunos momentos verdaderamente trágicos y sórdidos que justificarán, páginas más tarde, la huida del personaje y su creciente estado de psicosis personal. El miedo le hará recorrer la ciudad y forzará en el personaje una auténtica mutación psicológica que, en muchos momentos, alcanzará niveles propios de una auténtica metamorfosis, lo que explicaría, como veremos al final, las últimas imágenes de la novela.

El turbión arranca con el asalto a un edificio gubernamental, dedicado a los servicios de información del régimen, donde supuestamente están escondidos los cuadros más represivos de la maquinaria dictatorial y en donde, según la versión inicial de García Márquez, estaban encerrados los presos políticos. La multitud, convertida en una masa irracional, rodea y hostiga al personal que se encuentra en su interior y mientras espera para ejecutar su particular asalto al poder, va a ser responsable de algunos episodios que permiten extender y desparramar la barbarie más allá de la propia dictadura, ejemplificando a la perfección lo que el escritor Elias Canetti llamó «masas de acoso»:

La masa de acoso se constituye teniendo como finalidad la consecución rápida de un objetivo. Este le es conocido y está señalado con precisión; se encuentra, además, próximo. La masa sale a matar y sabe a quién quiere matar. Con decisión incomparable avanza hacia esa meta, y es imposible escamoteársela. Basta con dársela a conocer, basta con comunicar quién debe morir para que se forme la masa. La determinación de matar es de índole muy particular y no hay ninguna que la supere en intensidad. Todos quieren participar, todos golpean. Para poder asestar su golpe, cada cual se abre paso hasta llegar al lado mismo de la víctima. Si no puede golpear, quiere ver cómo golpean los demás [...]. Una razón importante del rápido crecimiento de la masa de acoso es la ausencia de peligro. No hay peligro porque la superioridad de la masa es enorme. La víctima nada puede contra ella. $\mathrm{O}$ huye o queda atrapada. No puede golpear; en su indefensión es solo víctima. Pero ha sido entregada para que la aniquilen. Ese es su destino, y nadie debería temer sanción alguna por su muerte (Canetti, 2005: 113-114).

En los primeros lances de la novela, un ciudadano trata de escapar corriendo mientras que otro le golpea con un machete, en medio del júbilo y el entusiasmo de la muchedumbre: «La cabeza del fugitivo saltó cercenada y rebotó por el asfalto, llevándose la corbata prendida como la cola de una cometa, hasta quedar varada junto a los restos de uno de los automóviles incendiados, que todavía humeaban. El cuerpo del decapitado [...] giró como si hubiera sufrido un vértigo y cayó borbotando sangre, tal una redoma que se vuelca» (p. 18).

Al verdugo lo reciben como si fuera un héroe deportivo del mundo del béisbol, al grito unánime de «iMuerte a los espías!». Por otro lado, la llegada de camiones con soldados, cuyo papel es de una ambigüedad deliberada, multiplica hasta lo indecible la crispación del entorno, con un ejército que bascula entre los nuevos aires revolucionarios y la lealtad a las estructuras más corruptas del estado totalitario. Nada sabemos del ciudadano decapitado, y poco más de «un simple oficial "C" con sueldo de 
trescientos bolívares a la quincena» (p. 22), quien al salir del edificio gubernamental se arrodilla en actitud suplicante para mofa y escarnio de la plebe y de los soldados que disfrutan con su cobardía. Este simple oficial descubre entre los centenares de bocas que gritan la de un conocido suyo, Eladio Ulises Rangel, Rangelito en la intimidad, pero este hace caso omiso a las súplicas de quien resulta ser su compadre, el padrino de su hija, un hombre bueno que nunca ha hecho mal a nadie y cuyo error definitivo ha sido estar en el lugar inapropiado en el momento más inoportuno. En su huida desesperada va a ser cazado como si fuera una alimaña cualquiera: «El huido cayó a tierra y ya no se le volvió a ver. Cuando era solo un guiñapo, una marioneta, dos individuos de aquel apretado y bamboleante hervidero humano, y porque algo había que sacar a la evidencia pública, a la luz del sol, le alzaron por un brazo» (p. 23).

La muchedumbre trata de ver algo del «linchado: un mechón de pelo, un ojo, un gesto, tal vez un pedazo de entraña», pero solo queda de ese oficial «C» una cabeza «virtualmente lapidada y empezando a confundirse con el asfalto» (p. 24). En otras ocasiones la multitud persigue a los sospechosos «con piedras y palos, machetes, cuchillos, pedazos de cabillas» (p. 25). En medio del griterío y la confusión creciente, son varios los inquilinos del edificio gubernamental, haciéndose pasar por presos políticos, quienes consiguen escapar saltando como liebres por las vallas y las tapias de los jardines de las casas colindantes y es ahí donde un grupo de asaltantes llega buscando a los huidos en la Pensión Orense, donde hay, fundamentalmente gallegos inmigrantes, algunos de ellos, posiblemente, exiliados, en cualquier caso gente con condiciones de vida muy precarias que ha llegado a esta república latinoamericana para tener una nueva oportunidad y que en cualquier caso, desean permanecer al margen del estallido social y en el más que deseado anonimato frente a la amenaza que se cierne sobre los más débiles:

ninguno de los pupilos de la pensión, esperaban libertad alguna con el cambio político que se producía y que ya se estaba viendo venir desde hacía una semana de ininterrumpidos acontecimientos. Esto, la política, quedaba para los hijos del país. Que ellos, los emigrantes, estaban en aquella tierra sin otras miras que las del trabajo fácil y la cuenta de ahorro en dólares, ésta no tan fácil, pero, al fin y al cabo, abierta por casi todos, para unos con fruto, para otros con dolor y para todos con esperanza (p. 34).

Sin embargo, nadie parece a salvo del feroz empuje de la muchedumbre desquiciada y ningún lugar resulta seguro ante la violencia que repunta en cada esquina, en cada calle, en cada edificio:

El resto de los evadidos van siendo atrapados y muertos. Con saña. Como perros. Sin piedad. A cantazos, a golpes de estaca, a puntapiés. Tal si fueran alimañas. Y con la vida se les ha despojado también de cuanto llevaban encima. Algunos incluso han sido identificados cuando ya ni alentaban siquiera [...]. Porque, efectivamente, no eran presos políticos, sino agentes de la policía gubernamental. No; no eran, ciertamente, presos políticos; pero ¿quién puede negar a estos hombres, ahora y post-mortem, la condición de muertos políticos, de muertos por la política? [...] ¿Quién lo iba a decir hace solo unas horas, antes de la caída del gobierno? Y es que la política es una gran ramera, cruel e inconsecuente, de verdad dictadora, que no admite la sustitución sin la eliminación. Al menos en una gran cantidad de países (p. 26).

Cuando el ejército trata de disolver a la muchedumbre amenazándola con abrir fuego, uno de los paisanos dice: «En este país, la gente del sable será siempre la que 
mande. Está visto» (p. 26) y no le falta razón, porque en el arranque de El turbión todo son disparos, morteros, cristales rotos, incendios, gritos, militares que van y vienen, que se mueven de manera ambigua y zigzagueante entre la lealtad al dictador y los nuevos aires del linchamiento revolucionario, lo que podría interpretarse en clave metonímica como referencias implícitas a nuestra propia Guerra Civil, y también a la violencia secular que ha sacudido a los pueblos americanos.

El protagonista de la novela, Efrén, tiene que huir porque en el registro de la Pensión Orense, epicentro local de los movimientos migratorios de la posguerra española, alguien lo confunde con un torturador del régimen que acaba de fugarse, llevando ropas muy parecidas a las que - fatalmente - lleva puestas el inmigrante andaluz. Es don Indalecio, un maestro republicano en el exilio, quien le aconseja que salga y huya inmediatamente, hasta que amaine el temporal, hasta que escampe esta nueva tormenta tropical que va a dejar el paisaje humano devastado por la violencia y la locura colectiva, dando así una clara puntada en la interpretación semántica del título, El turbión, tal y como recoge el Diccionario en cualquiera de sus tres acepciones: DEL (Diccionario de la Lengua Española): turbión. De turbio. 1) Aguacero con viento fuerte, que viene repentinamente y dura poco; 2) Multitud de cosas que caen de golpe, llevando tras sí lo que encuentran; 3) Multitud de cosas que vienen juntas y violentamente y ofenden y lastiman.

De lo físico a lo metafórico, de lo inmediato a lo simbólico, Efrén parece estar viviendo cada una de las posibilidades interpretativas del término «turbión», porque es eso, una tormenta devastadora lo que va a vivir durante veinticuatro largas horas en un periplo incierto y a veces agónico que le llevará de un extremo a otro de la ciudad, activando para el lector una suerte de cámara subjetiva que nos permite ver cómo una ciudad entera está siendo saqueada y violentada, aprovechando el vacío de poder tras la caída del dictador. ${ }^{6}$ Efrén recorrerá calles, plazas y avenidas, tratará de recordar las direcciones y teléfonos de la poca gente con la que se ha relacionado, a pesar de llevar ya siete años trabajando en ese país, y vivirá sin quererlo toda una serie de peripecias extrañas e insólitas que trazan los resortes de su nueva identidad, en ese viaje con valor iniciático que lo lleva por lugares como el corral de vecinos donde vive su amigo portugués Abilio de Dan, la casa donde vive el ingeniero español Ayucar junto con su familia, la plaza Bolívar donde se reúnen todos los fines de semana los inmigrantes portugueses, italianos y españoles, la zona rica donde ha sido desvalijada la casa colonial del exministro del interior del gobierno depuesto o las obras de extrarradio donde un Efrén envalentonado va a vivir una experiencia erótica que sirve como contrapeso y alivio a la propia gravedad de la trama argumental.

En realidad, lo que percibe el lector en este periplo es aquello que ve con sus propios ojos un atemorizado y atolondrado Efrén, que se mueve a golpes de consejos e

${ }^{6}$ Resultan de gran interés las novelas que concentran en muy pocas horas o días toda una cosmovisión histórica, la mayor parte de las veces de índole traumática. A las obras que cito a continuación, y que ya aparecen en trabajos míos anteriores, habría que añadir El turbión (1967) de Acquaroni; así ocurre en Las últimas horas (1949) de José Suárez Carreño, La colmena (1951) y San Camilo 1936 (1969) de Camilo José Cela, La noria (1951) y Tres días de julio (1967) de Luis Romero, Réquiem por un campesino español (1953) de Ramón J. Sender, El Jarama (1955) de Rafael Sánchez Ferlosio, Duelo en el Paraíso (1955) de Juan Goytisolo, Dos dias de septiembre (1962) de José Manuel Caballero Bonald o Cinco horas con Mario (1966) de Miguel Delibes. A esta lista habría que sumar algunos ejemplos rutilantes de la literatura hispanoamericana, como La muerte de Artemio Cruz (1962) de Carlos Fuentes, El lugar sin límites (1966) de José Donoso, Conversación en La Catedral (1969) de Mario Vargas Llosa o Crónica de una muerte anunciada (1981) de Gabriel García Márquez. 
intuición por una ciudad semidesconocida, dispuesta a devorarlo. La mirada de Efrén, y por tanto la del narrador, no se detiene en el entusiasmo de las masas, en la creciente esperanza con que se vive todo declive de una dictadura o en las nuevas oportunidades e ideales que se proyectan hacia el futuro, sino que parece regodearse en aquellos aspectos más sórdidos de la muchedumbre humana, convertida en auténtica «marabunta», que parece arrasarlo todo a través del saqueo y el sistemático desvalijamiento de aquello que tiene algún tipo de valor. Algunos ejemplos.

Una vez que el edificio gubernamental ha sido desalojado al comienzo de la novela, una multitud crispada y encolerizada ocupa los interiores del inmueble para no dejar un azulejo vivo, convirtiendo la sed de venganza y el linchamiento en un vulgar acto de rapiña:

La ruidosa marea humana avanza ya sin contención, a toda velocidad. Se entra por las puertas del edificio, por las ventanas, saltando la verja del estacionamiento... Y las cuatro plantas de la mole gris aquella, el centenar y pico de sus dependencias, sus sótanos y calabozos, van absorbiendo, por todos los huecos bajos de sus cuatro fachadas, aquella inmensa multitud que rebulle, que sube y baja, que registra ficheros y carpetas, que riega de papeles los suelos, que abre gavetas apalancándolas, que destroza muebles, que exhibe, entre aspavientos, supuestos instrumentos de tortura; que trinca, avalora y suelta, para volver a trincar; que hurga y rebusca por todos los rincones; que agavilla los más diversos objetos — unas viejas botas de campo, un perchero, un flexo de mesa, el muelle cojín de goma espuma de una butaca, la revista o la engrapadora encontrada sobre una mesa...-; que expolia o lo arrasa y destruye todo... Así, un hombre, a duras penas, está sacando por una ventana un pesado refrigerador de aire, y una mujer, ayudada por un rapaz no mayor de seis o siete años, asoma por una de las puertas laterales, agobiada por el peso de un camastro de hierro.

En unos minutos, la plaza se convierte en un hormiguero de acuciosas criaturas, portadoras de las más diversas cosas, cuyo objetivo, la violencia y la muerte, ha cambiado por el saqueo y el botín (p. 30).

Cuando llegan a la Pensión Orense con el argumento de atrapar a los esbirros del régimen que han conseguido huir, la cacería humana muta en un descarado mangoneo de la precaria propiedad privada, aprovechando el estado de indefensión de los sufridos huéspedes del local, recreándose el narrador en detalles que sirven a José Luis Acquaroni para retratar la miseria humana:

Y en un abrir y cerrar de ojos, ante el miedo y la forzada pasividad de los huéspedes, se registraron armarios, modestas maletas de arpillera y cartón, que estaban sobre los guardarropas o bajo las camas; el baúl barato de madera y guarniciones de hojalata, que se comprara, allá en la aldea lejana, antes de la partida, a algún guardia civil... Y en menos que canta un gallo fueron desapareciendo maletas, prendas de vestir, recuerdos familiares, la escondida caja de ahorros, la radio que estaba sobre el aparador del comedor, la batidora, en la cocina, y hasta una fotografía dedicada por un torero famoso [...]. Tal era la batahola, que hasta desapareció el trozo de chorizo, casi dos tercios, que Purificación tenía preparado para la paella, y el tocadiscos del vocalista portugués Zé de Vila (p. 38).

Tampoco se libra el profesor don Indalecio, el maestro republicano en el exilio, al que roban su máquina de escribir, «adquirida con los primeros ahorros de la emigración», su sombrero panameño, necesario para cubrir lo que él llama «la calva senequista», el flexo de la mesa y hasta un par de zapatos, con todo lo que ello 
representa (p. 39). Horas más tarde, en plena huida, Efrén contempla estupefacto cómo grupos perfectamente organizados practican una suerte de alunizaje con un camión, utilizado como ariete, para saquear el interior de unos almacenes, del que se van a llevar hasta las estanterías. Pero quizás el momento más tenso lo vive de modo casual frente a la casa colonial del exministro del interior, considerado entonces como el enemigo público número uno de la república. La mansión, completamente desprotegida a pesar de los soldados y policías que se encuentran en los jardines de la hacienda, supuestamente para custodiarla, va a ser objeto de un desmantelamiento sistemático de todo aquello que la reviste por dentro y por fuera, perpetrado, como dice el narrador por «una plaga enorme de insectos» (marabunta), que va a arrasar con todo:

se percibe como si una plaga enorme de insectos, una carcoma de efectos rapidísimos estuviera consumando en solo unos minutos su implacable tarea demoledora. Efrén no lo veía todo, pero advertía desde el jardín el inquieto destornillar de camas, el desarmar de pesados muebles, un removerlo y desquiciarlo todo. La gente salía cargada con lo que fuese: butacas, colchones, líos de prenda, cuadros, botellas, la nevera, la cesta de la ropa sucia... Todo el orden de aquella casa, un orden logrado a través de muchos años, pausada y detalladamente, venía a quebrarse en unos instantes. Excepto las paredes y los techos, el resto se desmoronaba, perdía su condición de gran familia, de cosas y objetos jerárquica y armónicamente dependientes. Las piezas maestras de la cama cedían y hacían caer con estruendo a las demás; la butaca enseñaba su entraña burda y esquemática; los cuadros, sus reveses de toscos lienzos... Las alfombras eran enrolladas a puntapiés, para facilitar su acarreo; los libros aparecían desparramados, pisoteada, violada la intimidad de sus páginas... Todo desordenado, revuelto, subvertido, camino de la subasta callejera o del nuevo destino, en donde muchas de estas piezas serán por mucho tiempo como huéspedes extraños, como seres de otra clase social, hasta acabar aceptadas por la costumbre, unas veces, y otras, a fuerza de lograr parentesco a través del tiempo o la mugre (p. 58).

Llama la atención en la novela que nadie haga nada por frenar los múltiples actos de saqueo y pillaje que convierten la ciudad en un territorio devastado por la violencia y la inseguridad, salvo una mujer joven y hermosa, embarazada en estado ya avanzado, quien se presenta como la esposa del exministro; es ella quien defiende con uñas y dientes la biblioteca de la casa que está siendo cargada en cajas con el argumento peregrino de llevar los lotes bibliográficos a la biblioteca universitaria. Esa mujer, sacando fuerzas y entereza de sus entrañas, defiende una biblioteca que puede ser pasto de las llamas y que ha sido atesorada tras varias generaciones de familiares que han mimado la cultura libresca, quizás como un guiño bibliófilo del propio Acquaroni quien quiso responder ante la barbarie social y política con las armas de la cultura y el conocimiento atesorado en la biblioteca particular.

\section{LA IDENTIDAD COMO CONFLICTO}

La identidad es un elemento clave en el trazado argumental de la novela, a partir del mismo momento en que el protagonista es confundido con otro personaje, por una simple coincidencia en la forma de vestir. Cuando llegan al cuchitril de Efrén y de su amigo Hernando (vallisoletano), lo describen con el moreno albañil: «No era el color moreno verdoso del indio, ni el acaobado del mulato, ni mucho menos el tono ébano del africano» (p. 40). El conflicto con el grupo se va a producir porque va vestido de 
manera elegante, de una forma parecida a uno de los «esbirros» del edificio gubernamental. Efrén siente pánico en primer lugar porque le roben lo que a duras penas ha conseguido ahorrar, «los mil dólares en su cuenta de ahorro, cantidad que en su España no suponía ninguna tontería» (p. 40). Tras la confusión derivada de su forma de vestir, el dueño de la pensión, llamado Segundo, sale en su defensa: «Este muchacho que decís es un espía, no es más que un desgraciado albañil, que no se mete con nadie, que lleva dos años en esta casa y que yo lo conozco como si lo hubiera parido» (p. 44). También don Indalecio intercede por el humilde trabajador:

-Yo os aseguro, y respondo por ello, que este hombre no es de los que buscáis. Este muchacho es español, albañil de oficio, y desde que yo le conozco, que hace ya algún tiempo, ni se mete en pendejadas de política...

- La política no es una pendejada, profesor...

-Eso será para ustedes los españoles.

-... ni es agente secreto, ni nada que se le parezca. Y que enseñe su documentación, que por ahí debiéramos de haber empezado.

-Muchos de los agentes tienen documentación falsa, profesor (p. 45).

Este albañil que «nada sabe de detenciones, de torturas ni de vainas de ésas...» (p. 45) se va a ver en la necesidad de huir de ese espacio conflictivo y lleno de confusiones y equívocos personales, tal y como le aconseja el sabio profesor, a la espera de que escampe y pase este particular «turbión» político. A partir de este momento todo son tensiones, miedos, angustias, cierto grado de psicosis personal, de sentirse vigilado, perseguido, señalado por cada uno de los asaltantes que se cruzan en su camino. Eso va a propiciar que en algunos momentos trate de camuflarse y pasar desapercibido y que en otros segmentos de la novela reivindique su condición de inmigrante andaluz, sobre todo cuando trata de pedir ayuda inútilmente a las instituciones hipertrofiadas del franquismo como así ocurre en la embajada española en territorio americano, tal y como señalaba en una de las reseñas pioneras de 1967 Miguel Ángel Pastor, para quien «late en estas páginas un trasfondo españolísimo, una acusación indirecta ante el abandono de la emigración y un dolor traspasado de las mejores esencias nativas» (en Arroyo García, 2000: 125). De nada sirve en el comienzo de la obra que trate de enseñar su pasaporte y sus papeles en regla porque, como dice uno de los perseguidores, puede tratarse de papeles falsos y no faltan, precisamente, los espías y colaboradores del régimen de origen extranjero. La situación se complica tanto para un inmigrante español que queda aterrado al leer en una pancarta el siguiente lema: "Con las tripas de los italianos colgaremos de los árboles a los españoles» (p. 104).

Al entrar en un cafetín chino para pedir algo de comer trata de disimular su acento andaluz y llega a reprimir en su habla expresiones tan castizas - y cervantinascomo el «vale» para evitar que lo identifiquen como español. Antes de decirle al camarero chino «Vale, dame otra arepa y otro café», se da cuenta de que esa expresión lo identifica entre la muchedumbre, lo vuelve más extranjero, más ajeno a ese mundo («empleando términos de la más castiza jerga»), al punto de que su identidad lingüística se convierte en un conflicto, en un peligroso señuelo en medio de la violenta algarabía del momento (p. 91). Por otro lado, su aspecto exterior, su perfil humano, su fenotipo, en definitiva, nos permite imaginar a Efrén como un trabajador andaluz. El personaje llega a indignarse con el trato que le dan en la embajada, cuya indiferencia y frialdad burocrática e institucional provocan un verdadero socavón en estas horas cruciales de su huida: 
«¿Es usted español?» La interrogante le hacía otra vez sentirse inquieto, inseguro. Decididamente, ni su pelo negro, ni sus ojos oscuros, ni sus facciones un tanto agitanadas lo identificaban claramente español. En aquel mundo de indios, mestizos, italianos, portugueses..., estaba visto que él, por su físico, podía pertenecer a cualquiera de estas razas. Menos negro o nórdico, todo podía ser. E indígena, al parecer, lo que más. Tal vez por su ceceo andaluz, los muchos indicios criollos se acrecentaban al hablar. En resumen: que tenía que demostrar de alguna manera su nacionalidad. Su físico y su habla no hacían sino inducir al error (p. 78).

La identidad (y nacionalidad) del personaje está planteada de manera conflictiva en muchos momentos de la novela, en parte por las tensiones xenófobas que generan los flujos migratorios, cuando se juega con la idea de que los inmigrantes, los viajeros, los exiliados o desplazados vienen a quitarle el trabajo a la población autóctona. Por uno de esos extraños bucles temporales, José Luis Acquaroni da una pincelada certera sobre inmigración y xenofobia que parece valer para cualquier lugar y para cualquier momento:

Los extranjeros desplazaban a los nativos de muchos puestos de trabajo y, sobre todo, los forzaban a un ritmo laboral al que no estaban acostumbrados, y la xenofobia aparecía en cuanto era posible dar rienda suelta a la demagogia y al libertinaje. La pancarta era más bien pequeña y había que acercarse a solo unos metros para leerla. Pero la gente, al conocer el sentido de lo escrito, se mostraba alborozada y aplaudía: señal de que el espíritu de la retorcida frase estaba muy vivo en el ánimo de la mayoría (p. 105).

En este sentido, se siente muy vulnerable y desprotegido cuando recurre al ingeniero Ayucar, posible exiliado español, quien también se encuentra a la intemperie en la nueva situación política y ante la petición de ayuda le contesta:

- ¿Y qué otra cosa puedo yo hacer, muchacho?... Tan extranjero como tú soy yo en estos momentos, y pocas seguridades de protección podría darte. Mis amigos del gobierno, vete a saber en qué madrigueras se andarán escondidos en estos instantes... Además, en una situación como la presente, no esperes ningún tipo de garantía de nadie. Si hasta la policía, como habrás leído, prácticamente no existe, y el país entero se haya a merced de cuanto insensato quiera imponer su ley actuando en nombre de la revolución (p. 75).

Cuando va a ver al guardián de la obra en la que terminará refugiándose, un borrachín de pocos escrúpulos llamado Abigaíl, se encuentra con esta conversación a voz en grito en uno de los tugurios del extrarradio de la ciudad:

- Ahora lo que tienen que hacer es devolver a sus respectivos países a todos esos pendejos de italianos, portugueses, españoles... — decía Abigaíl en el momento de entrar Efrén en la taberna.

-Y los del Norte, ¿qué? -interpeló otro del grupo-. Los del Norte que se larguen a su Texas, y si allí nada tienen que perforar, que se metan las sondas en el c... (p. 104).

Ante el asombro y la indignación de Efrén, Abigaíl matiza algo su discurso: «Bueno, algunos españoles pueden quedarse. Pero ¡a dar el callo, eh! A arrimar el hombro así como lo arrima el ciudadano Efrén $-\mathrm{y}$ le daba a éste palmaditas en la 
espalda - Los otros, los del cuento, la especulación y la guarandinga, ${ }^{7}$ que se vuelvan con los godos y la madre que los parió» (p. 104).

Sin embargo, lo que más nos interesa en la construcción identitaria del personaje son los numerosos saltos temporales o flashbacks que nos sitúan siete años atrás, en una tierra marinera, amorosa y cruda en sus recuerdos, que remite necesariamente a la infancia sanluqueña de José Luis Acquaroni. A partir de ciertos destellos de su memoria recuperamos la primera juventud de Efrén, sus devaneos amatorios con sabor a playa, su fallida relación con Caridad, la hija de los porteros de un convento, que decide casarse con el hijo un poco lelo del escribano de la notaría, el recuerdo de la humedad y del frío de invierno que se cuela entre las rendijas de su casa, la presencia del mar que va y viene por su memoria, dejando un reguero de espumas y nostalgias en el personaje, el dolor por «la muerte y enterramiento de su madre, sin la presencia de él, el hijo emigrante y aventurero» (p. 71). El pasado sanluqueño también se filtra en las zonas recónditas del personaje a través de los mecanismos oníricos, que lo llevan a soñar con la habitación de su infancia a donde arrojan y apilan cadáveres, como si fueran fardos, atunes o pellejos de vino, en lo que parece una referencia implícita a los horrores de la Guerra Civil. En el sueño convertido en pesadilla, Efrén se ve a sí mismo en su pueblo natal, saliendo de casa de sus padres, muy cerca del mar y es en ese espacio, que bascula entre lo familiar y lo indómito, donde se produce una de las imágenes más aterradoras del sueño, como una forma de representación de la angustia que está viviendo el personaje:

A medio centenar de metros de la orilla se encontraba un trasatlántico hundido, asomando sobre las aguas parte de la superestructura de popa, el puente alto, media chimenea y uno de los palos. Toda el agua en derredor del navío aparecía poblada de cadáveres de marineros. Cadáveres gigantescos, desproporcionados, como si el buque fuera de juguete.

Estaba Efrén sin atreverse a trasponer el dintel de la puerta de su casa, cuando inesperadamente se presentaron unos empleados de la comandancia de Marina. Efrén quiso hablarles, pero no le hicieron caso. Los funcionarios se pusieron sin más a extraer cadáveres del mar y a introducirlos en la casa de Efrén. Al principio, los cadáveres eran transportados de uno en uno, porteados entre dos hombres, el uno por los pies y el otro por la cabeza. Cuando llegaban a la puerta de la casa de Efrén, los lanzaban a un rincón, donde los muertos iban amontonándose. Efrén protestó, es verdad que demasiado levemente, sin fuerzas casi: tal era el pavor que sentía. Pero los empleados siguieron haciéndose los sordos. Aún peor: a raíz de la protesta los cadáveres empezaron a ser proyectados directamente desde la orilla a las habitaciones de la casa. Entraban por puertas y ventanas, rebotando sobre el suelo, como fardos, como pellejos de vino, prietos de agua, del agua tragada, haciendo un ruido espeluznante y sobrecogedor.

De vez en cuando los funcionarios de la Marina entraban en la casa y, silenciosos e indiferentes, se ponían a la tarea de apilar los cuerpos sin vida. Sobre el suelo quedaba una gran charca de agua salada y sangre coagulada, sobre cuyos grupos los hombres pisaban con sus grandes botas de goma [...]. Efrén entonces, en su desesperación, incomprensiblemente condenado a no poder escapar de su casa, miraba de soslayo hacia los rostros de los cadáveres, enmarcados por largas melenas, bañados en sangre y negro petróleo, con gestos y expresiones terribles (pp. 133-134).

${ }^{7}$ Según el Diccionario de americanismos se trata de un venezolanismo que significa «Cosa cuyo nombre se desconoce o que no se quiere mencionar. Cosa de poco valor. Broma, falta de seriedad. Ambiente de confusión y desorden. Asunto molesto y desagradable». 
Es muy posible que en el origen de estas imágenes truculentas se encuentren otras reales, vividas en su propia persona, o conocidas directa o indirectamente a través del repertorio inacabable de los horrores de la guerra, imágenes impactantes que golpean la sensibilidad del lector por lo que supone de banalización de la muerte, de ultraje y humillación hacia los muertos, que son tratados sin el mínimo decoro exigido, alterando así todo ritual o protocolo relacionado con la muerte y truncando, de esta forma, la necesidad de drenar el dolor por la pérdida y aliviar la ausencia por medio del luto necesario. Los cuerpos amontonados en cualquier rincón de la casa, arrojados contra la pared de la manera más abyecta imaginable, funcionan en el plano del sueño como una representación simbólica de un muladar o un vertedero. También como una imagen codificada que remite a las ejecuciones sumarias en cualquier pared o tapia de un cementerio, o a las fosas comunes de la época, que se acaban confundiendo con las imágenes tantas veces vistas por el propio escritor, en donde aparecen los grandes pescados de la lonja sanluqueña o gaditana, el agua que corre junto con la sangre y las vísceras, el chapoteo de los trabajadores entre los restos de la pesca, el espectáculo cruel y sanguinolento que le ofrece a Acquaroni un marco referencial espléndido para plantear la crueldad y la deshumanización de la contienda civil. Las víctimas son arrojadas y depositadas en cualquier «no lugar» (Augé: 2000), como si fueran atunes o cualquier pieza codiciada en el coto de caza mayor de la guerra.

Además del episodio anterior, con una evidente pulsión surrealista, hay en $E l$ turbión otros dos momentos que conectan el pasado doloroso con el presente incierto del personaje. En el primero de ellos, mientras están saqueando los comercios de una calle céntrica de la ciudad, Efrén queda atrapado ante el escaparate de una tienda de animales donde contempla extasiado el interior de una pecera, que funciona como recurso proustiano para activar su memoria «sanluqueña» y por tanto su identidad gaditana y andaluza, que tiene mucho que ver con el final de la novela:

Los peces, las algas y, sobre todo, aquella pálida arenilla lavada le hicieron recordar a Efrén su tierra, su pueblo. Rememoró la playa de su pueblo, en el sur español; la barriada de pescadores, donde viviera tantos años, con las negras y grasientas tabernas abiertas toda la noche, y un trajín permanente en almacenes, patios de red y varaderos.

No sabía por qué, y pese a que era pleno mediodía, aquellas luces de la pecera le hacían recordar su pueblo en la noche, durante las gélidas noches del invierno, de pies descalzos y acorchados por la arena húmeda y el agua. Se imaginó el mar, su mar, bajo la luna de enero y, tierra adentro, sobre la mediana loma, el resto del pueblo, «la gente del campo», como allí decían, dormido, insignificante como un aprisco en medio del majadal, todo él coronado por el viejo castillo y sin otros ruidos que el ladrar de algún perro medroso, el maullar de los gatos en celo o el chirriar de los goznes de un portalón por el que alguna bestia enferma se dejaba en libertad camino del abrevadero (p. 52).

El segundo momento está localizado en el final de la novela, en un nuevo amanecer, veinticuatro horas después de iniciada la fuga. Frente al mundo urbano en el que ha transcurrido el grueso de la acción, con todos los ingredientes propios de la literatura citadina y asfáltica, el personaje se desplaza hacia la periferia de la ciudad, hacia los macizos selváticos, con su naturaleza lujuriosa y exultante que parece querer abrazar y fagocitar las construcciones levantadas por la mano del hombre. Este desplazamiento desde el centro - plaza Bolívar- hacia la periferia, trae hasta la memoria del lector una de las dicotomías más rentables de la literatura hispanoamericana, como es el binomio civilización-barbarie, para situarnos en otras formas más sutiles y atávicas del miedo, como es el que siente el hombre indefenso ante 
las alimañas y los animales salvajes, pero fundamentalmente el relacionado con las serpientes, lo que trae hasta la memoria del lector las leyendas locales, que tienen su raigambre en el mundo rural y muy especialmente en el territorio andaluz y sanluqueño: «De otras "bichas" había oído cosas insólitas: por ejemplo, que succionan de las ubres de las vacas, y aun de los pechos de las mujeres mientras se adormilan éstas dando de mamar a los hijos, a los que entretienen introduciéndoles la cola en la boca a modo de pezón» (p. 155). ${ }^{8}$

José Luis Acquaroni certifica así el paso de un miedo social y urbano, a otro más ancestral y telúrico, relacionado con experiencias remotas que anidan en lo que el antropólogo francés Lucien Levy-Bruhl llamó El alma primitiva del hombre (1927). En su afán por escapar de la ciudad, el personaje piensa que «el campo, mejor. El campo y sus caminos, que alejan de la urbe» (p. 153). Por el contrario, lo que quiere es camuflarse en medio del espacio natural: «Lejos, lo más lejos posible de aquellas calles y aquellas plazas en donde se cazaba a los hombres como si fueran alimañas. Lo que le interesaba era simplemente "hacer la culebrina", como decían por su pueblo, vagar» (p. 153).

Este viaje desde el centro de la civilización hasta los confines del mundo natural es uno de los rasgos habituales de la narrativa hispanoamericana, visible en multitud de novelas, que van desde La vorágine de José Eustasio Rivera a Los pasos perdidos de Alejo Carpentier, desde las crónicas de Indias a la llamada «literatura terrígena», propiciando una suerte de viaje centrífugo, hacia el exterior, lejos de la civilización, pero también centrípeto, hacia el interior de la naturaleza, como lo ha rastreado Fernando Aínsa (1976: 322), en una búsqueda que puede ser tanto del paraíso perdido, como la constatación de lo que el crítico Fernando Alegría ha considerado como el «mapa de la infamia» (Aínsa, 1976: 324). De hecho, en este viaje de Efrén hacia la periferia de la periferia, el personaje toma conciencia del espacio mancillado que se encuentra en la antesala del mundo telúrico, donde todo resulta sórdido y escatológico, presentando imágenes con un fuerte aliento fílmico con los vertederos enormes sobre los que sobrevuelan todo tipo de aves carroñeras y en donde la miseria física y social adquiere nuevas capas interpretativas. No es casual, en modo alguno, que una de las últimas imágenes que maneja el protagonista sea la del basurero lleno de inmundicias, como una metonimia del caos político que está viviendo, y más allá la naturaleza indómita, misteriosa, llena de peligros y de tentaciones, configurando lo que Aínsa ha llamado el «uso dramático del paisaje» (1986: 183):

Abrupta y hermosa geografía. Y a cada recodo, una sorpresa; la doble cinta de la moderna autopista, allá en lo hondo del desfiladero; el inmenso vertedero de basuras, con cientos de negros zamuros graznando su hambre, removiendo con el corvo pico envases, suciedades, desperdicios de comida, todo un podrido mundo de residuos e

${ }^{8}$ Un motivo parecido utiliza García Márquez para caracterizar a uno de los personajes más «invisibles» de Cien años de soledad, como es Santa Sofía de la Piedad, la mujer de Arcadio, la madre de Remedios la bella y los gemelos José Arcadio Segundo y Aureliano Segundo: «Nunca se le había oído un lamento a aquella mujer sigilosa, impenetrable, que sembró en la familia los gérmenes angélicos de Remedios, la bella, y la misteriosa solemnidad de José Arcadio Segundo; que consagró toda una vida de soledad y silencio a la crianza de unos niños que apenas si recordaban que eran sus hijos y sus nietos, y que se ocupó de Aureliano como si hubiera salido de sus entrañas, sin saber ella misma que era su bisabuela. Solo en una casa como aquella era concebible que hubiera dormido siempre en un petate que tendía en el piso del granero, entre el estrépito nocturno de las ratas, y sin haberle contado a nadie que una noche la despertó la pavorosa sensación de que alguien la estaba mirando en la oscuridad, y era que una víbora se deslizaba por su vientre» (1984: 432). Agradezco a mi alumna Patricia Duarte la información. 


\section{José Manuel Camacho Delgado}

inmundicias; la caseta para la venta de refrescos, y el pobre caserío adyacente, con los niños, desnudos, muy morenos, persiguiéndose entre los plátanos y los samanes; las barranqueras, sobrecogedoras, insondables y misteriosas de tan densas y umbrosas; el macizo vegetal, amurallado de troncos, enmarañado de lianas, empenachado de una riquísima gama de soleados verdes; los canceles de las fincas, abriendo umbríos carriles como túneles; el caminante mendigo o el tontiloco errabundo, dormitando a la sombra, sobre la acolchada hocarasca... Y, por todas partes, un murmurio de agua, de enramada acariciándose; un pálpito de pájaros, de ocultos reptiles, de sobresaltados insectos [...].

Miró hacia atrás, hacia el macizo vegetal que tenía a sus espaldas, y sintió la amedrentada inquietud de lo misterioso, ese auténtico pavor que se percibe ante los intrincados trozos selváticos. Miedo, sobre todo, por la posible aparición de alimañas y reptiles, las temibles serpientes que enseñoreaban los campos del país. ¡Horror a la mapanare, a la temible tragavenados, a la engañosa cascabel, todas ponzoñosas, todas amenazando la muerte en los pequeños espacios selváticos y hasta en las plantaciones habitualmente holladas por la planta del hombre! Recordó aquella «maraca» de una cascabel, que un compañero de trabajo guardaba como un talismán (pp. 154-155).

Miedo y familiaridad que recuerdan a muchos de los cuentos de serpientes del escritor uruguayo Horacio Quiroga. Entre el vertedero y la apoteosis de la naturaleza, el personaje solo parece reencontrarse a sí mismo cuando se sitúa frente a un océano que conecta las dos orillas de su memoria sentimental. La imagen final del personaje desnudándose completamente para introducirse en el mar ha sido interpretada por José Jurado no solo como un homenaje a su playa natal, insinuada en otros cuentos y relatos, sino también como un símbolo de regreso, de regresión, de vuelta al origen, a esa infancia o adolescencia convertida en el verdadero paraíso del hombre:

De Sanlúcar elige sobre todo la playa, el mar, como escenario frecuente en su literatura. Por ejemplo, en un cuento "Como agua» los personajes pasean por una playa que tiene un castillo. En «Un vagabundo va de vacaciones» este personaje se escapa de un asilo para ir a la playa. En «La muerte del trompeta», en un principio titulado «Suceso en la playa de Puerto Évora», los protagonistas acaban bañándose e incluso Silvino, el trompeta, termina ahogándose. En «Una cabeza» Félix, el mayordomo, aparece descalabrado en la playa. También el final de El turbión recoge el baño de Efrén en una playa venezolana. Valorando las distintas recreaciones literarias de esas playas inspiradas en la de Sanlúcar, puede convenirse que (junto a otras connotaciones puntuales) el mar es símbolo de la libertad personal, del reencuentro con uno mismo. El baño en la playa parece purificar a los personajes, devolverlos a la inocencia infantil, a la tranquilidad del útero materno. El agua les conduce al olvido, al equilibrio, a la paz, incluso al descanso definitivo: la muerte (Jurado, 2000: 38).

Es evidente que esa imagen final con la que Acquaroni quiere cerrar su novela resulta tan sugerente como enigmática y obliga a una relectura del pasaje en términos identitarios. Su llegada a la playa le ofrece un espectáculo tan hermoso como inquietante: «En un trecho de la orilla, las aguas no batían sobre la arena, sino sobre un como osario de árboles, un montón de blanquecinos leños, esqueletos de náufragos que las crecidas de los ríos cobraban a la selva y arrastraban luego hasta el océano» (p. 156).

Extasiado ante esta imagen sorprendente, con todo tipo de resonancias atávicas, Efrén decide quitarse esas ropas que tantos problemas le han acarreado desde que comenzaron los disturbios por la caída del dictador («Igualito que tú iba trajeado...»), para sumergirse en las aguas purificadoras del océano: «Y por primera vez en las veinticuatro horas, sabiéndose poco menos que imposible de identificar en su igualitaria 
desnudez adánica y en su estrecha comunión en el mar, su mar — que el mismo era en ésta que en aquella orilla-, Efrén olvidóse por completo de sus temores» (p. 157).

Esta inmersión en el agua posee, a todas luces, una riquísima lectura simbólica de la novela, un acto de bautismo, de redención y transformación en las aguas americanas, que ha permitido el desmantelamiento de parte de su identidad para abrazar otras formas más complejas y solidarias de la idiosincrasia trasnacional, como cuatro siglos antes hiciera el jerezano Álvar Núñez Cabeza de Vaca. En el capítulo XII de los Naufragios, titulado "Cómo los indios nos trujeron de comer», el cronista andaluz, en uno de los momentos más intensos de lo que se ha llamado el «discurso del fracaso», narra cómo era tanta la debilidad de los pocos hombres que habían sobrevivido en territorio americano, que al intentar botar una pequeña embarcación, absolutamente artesanal, un golpe de mar acabó de tumbar la chalupa, quedando los nautas medio ahogados, desnudos completamente, ateridos de frío y llorando amargamente la suerte torcida de su andadura conquistadora por el Nuevo Mundo. En ese momento de desnudez absoluta, en lo físico, en lo anímico, en lo social, en lo espiritual, fueron los indios quienes consiguieron paliar el frío y la necesidad extrema del puñado de náufragos con sus abrazos y su solidaridad, borrando de un plumazo las diferencias raciales, culturales, lingüísticas o religiosas entre los hombres, porque en la necesidad y en la desgracia todos los hombres son iguales. Cabeza de Vaca ha dejado para el lector de la época — y de nosotros mismos, como señalara Todorov (2001) — la idea de que esa desnudez había sido necesaria para el bautismo americano de estos hombres que empezaban a pertenecer a un mundo muy distinto del que habían partido una década antes. $^{9}$

9 «Como nosotros veíamos, que estábamos proveídos de pescado y de raíces y de agua y de las otras cosas que pedimos, acordamos de tornarnos a embarcar y seguir nuestro camino, y desenterramos la barca de la arena en que estaba metida, y fue menester que nos desnudásemos todos y pasásemos gran trabajo para echarla al agua, porque nosotros estibamos tales, que otras cosas muy más livianas bastaban para ponernos en él; y así embarcamos, a dos tiros de ballesta dentro en la mar, nos dio tal golpe de agua que nos mojó a todos; y como íbamos desnudos y el frío que hacía era muy grande, soltamos los remos de las manos, y a otro golpe que la mar nos dio, trastornó la barca; el veedor y otros dos se asieron de ella para escaparse; mas sucedió muy al revés, que la barca los tomó debajo y se ahogaron. Como la costa es muy brava, el mar de un tumbo echó a todos los otros, envueltos en las olas y medio ahogados, en la costa de la misma isla, sin que faltasen más de los tres que la barca había tomado debajo. Los que quedamos escapados, desnudos como nascimos y perdido todo lo que traíamos, y aunque todo valía poco, para entonces valía mucho. Y como entonces era por noviembre, y el frío muy grande, y nosotros tales que con poca dificultad nos podían contar los huesos estábamos hechos propria figura de la muerte. De mí sé decir que desde el mes de mayo pasado yo no había comido otra cosa sino maíz tostado, y algunas veces me vi en necesidad de comerlo crudo; porque aunque se mataron los caballos entretanto que las barcas se hacían, yo nunca pude comer de ellos, y no fueron diez veces las que comí pescado. Esto digo por excusar razones, porque pueda cada uno ver qué tales estaríamos. Y sobre todo lo dicho había sobrevenido viento norte, de suerte que más estábamos cerca de la muerte que de la vida. Plugo a Nuestro Señor que, buscando los tizones del fuego que allí habíamos hecho, hallamos lumbre, con que hicimos grandes fuegos; y ansí, estuvimos pidiendo a Nuestro Señor misericordia y perdón de nuestros pecados, derramando muchas lágrimas, habiendo cada uno lástima, no solo de sí, mas de todos los otros, que en el mismo estado vían. Y a hora de puesto el sol, los indios, creyendo que no nos habíamos ido, nos volvieron a buscar y traernos de comer; mas cuando ellos nos vieron ansí en tan diferente hábito del primero y en manera tan extraña, espantáronse tanto que se volvieron atrás. Yo salí a ellos y llamélos, y vinieron muy espantados; hícelos entender por señas cómo se nos había hundido una barca y se habían ahogado tres de nosotros, y allí en su presencia ellos mismos vieron dos muertos, y los que quedábamos íbamos aquel camino. Los indios, de ver el desastre que nos había venido y el desastre en que estábamos, con tanta desventura y miseria, se sentaron entre nosotros, y con el gran dolor y lástima que hobieron de vernos en tanta fortuna, comenzaron todos a llorar recio, y tan de verdad, que lejos de allí se podía oír, y esto les duró más de media hora; y cierto ver que estos hombres tan sin razón y tan crudos, a manera de 
Es evidente que tanto en el texto de Cabeza de Vaca como en el de José Luis Acquaroni las ropas representan el pasado, los valores, hábitos y costumbres de la vieja Europa, una forma de representar a la civilización, tal y como estudiara en su día Tzvetan Todorov (2001: 44) para explicar la reacción de Colón y sus hombres ante la ausencia de ropas (y de pudor) en el mundo indígena. En este contexto, la desnudez no es solo física, sino sobre todo cultural e histórica, como un paso necesario para abrazar en toda su potencialidad los nuevos resortes de la identidad americana, aunque sea como resultado de una fuga disparatada. Es así como esta novela imprescindible y necesaria invita al lector a una reflexión profunda sobre los límites de la identidad y la solidaridad en un contexto marcado por la violencia, como un estigma que actualiza y nos recuerda una y mil veces los peores momentos de la leyenda negra panhispánica, más allá del doloroso fracaso de las escurridizas utopías sociales. La novela de tema americano de José Luis Acquaroni constituye una obra importante en la recepción, percepción y valoración de los fenómenos políticos y sociales procedentes de la convulsa vida latinoamericana en el último siglo, conformándose como un reverso necesario a los grandes temas de la ficción hispanoamericana, consagrados en el canon narrativo que marcaron la excelencia literaria de los años del boom. A través de la huida y fuga de un inmigrante andaluz, cuya identidad ha sido cuestionada, el escritor sanluqueño ha ofrecido al lector una visión tan distinta como necesaria de la complejidad que entraña cualquier episodio traumático de la vida política hispanoamericana, centrando su ficción en los miedos y angustias de un personaje elegido entre la multitud, casi al azar, que debe defenderse con uñas y dientes para no ser devorado por el turbión político que se extiende como un calambre por la sociedad, tras la caída del dictador.

\section{OBRAS CITADAS}

Aínsa, Fernando (1976), «La demarcación del espacio en la ficción novelesca (el ejemplo de la narrativa latinoamericana)», en S. Sanz Villanueva y Carlos J. Barbachano (eds.), Teoría de la novela, Madrid, Sociedad General Española de Librería, pp. 305-352.

Aínsa, Fernando (1986), Identidad cultural de Iberoamérica en su narrativa, Madrid, Gredos.

Arroyo García, Alejandra (2000), «Cuando los dioses tienen sed... Estudio de El turbión», en En busca de la literatura de José Luis Acquaroni (1919-1983). Más allá de la muerte en el olvido, Cádiz, Servicio de Publicaciones de la Universidad de Cádiz, pp. 119-140.

Augé, Marc (2000), Los no lugares. Espacios del anonimato, Barcelona, Gedisa.

Calviño Iglesias, Julio (1985), La novela del dictador en Hispanoamérica, Madrid, I.C.I., Ediciones Cultura Hispánica.

Camacho Delgado, José Manuel (2016), Sic semper tyrannis. Dictadura, violencia y memoria histórica en la narrativa hispánica, Madrid, Iberoamericana-Vervuert.

Canetti, Elias (2005), Masa y poder, Barcelona, Debolsillo.

García Márquez, Gabriel (1984), Cien años de soledad, Madrid, Cátedra.

Jurado Morales, José (2000), «El camino reconstruido: silencios y olvidos en la vida y la obra de José Luis Acquaroni», en José Jurado Morales (ed.), En busca de la literatura de José Luis Acquaroni (1919-1983). Más allá de la muerte en el olvido, Cádiz, Servicio de Publicaciones de la Universidad de Cádiz, pp. 27-45.

brutos, se dolían tanto de nosotros, hizo que en mí y en otros de la compañía cresciese más la pasión y la consideración de nuestra desdicha» (Álvar Núñez Cabeza de Vaca, Naufragios, capítulo XII: «Cómo los indios nos trujeron de comer»). 
Jurado Morales, José (2018), «Los inicios literarios de José Manuel Caballero Bonald a partir de su correspondencia con José Luis Acquaroni: 1951-1961», Bulletin of Spanish Studies. Hispanic Studies and Research on Spain, Portugal and Latin America, vol. 94, 8, pp. 815-838.

Jurado Morales, José (2020), «Las cartas cruzadas entre Fernando Quiñones y José Luis Acquaroni (1950-1952)», en José Jurado Morales, Alberto Romero Ferrer y Nieves Vázquez Recio (eds.), Si yo les contara... Estudios sobre Fernando Quiñones, Gijón, Ediciones Trea, pp. 413-429.

Mendoza, Plinio Apuleyo (1982), El olor de la guayaba, Barcelona, Bruguera.

Noguerol Jiménez, Francisca (1992), «El dictador latinoamericano (aproximación a un arquetipo narrativo)», en Philologia Hispalensis, VII, pp. 91-102.

Rentería Mantilla, Alfonso (1979), García Márquez habla de García Márquez, Bogotá, Rentería Editores.

Sandoval, Adriana (1989), Los dictadores y la dictadura en la novela hispanoamericana 18511978, México, UNAM.

Todorov, Tzvetan (2001), La conquista de América. El problema del otro, México, Siglo XXI.

Zuluaga, Conrado (1977), Novelas del dictador y dictadores de novela, Bogotá, C. Valencia Editores. 